\title{
Assessment of Varietal Performance in Diverse Potato (Solanum tuberosum L.) Genotypes
}

\author{
Smita Agrawal ${ }^{1 *}$, R. K. Jaiswal ${ }^{1}$, S. Kadwey ${ }^{2}$, Sunil Prajapati ${ }^{2}$ and Nancy Jaswani ${ }^{1}$ \\ ${ }^{1}$ Dept. of Horticulture, Collage of Agriculture Indore, Rajmata Vijayaraje Sindhia Agriculture University, Gwalior, Madhya \\ Pradesh (474 002), India \\ ${ }^{2}$ Dept. of Horticulture, J. N. Krishi Vishwa Vidyalaya, Jabalpur, Madhya Pradesh (482 004), India
}

\section{Article History}

Manuscript No. AR1740a

Received in $27^{\text {th }}$ November, 2016

Received in revised form $30^{\text {th }}$ November, 2016

Accepted in final form $6^{\text {th }}$ December, 2016

\section{Correspondence to}

*E-mail: smitaagrawal1558@ gmail.com

\section{Keywords}

Potato, varietal performance, Kufri Arun, potato tuber yield

\begin{abstract}
The present investigation was carried out during 2013-2014 at Experimental Research Farm, College of Agriculture, Indore, Rajmata Vijayaraje Sindhia Agriculture University, Gwalior (Madhya Pradesh). The experimental material for the present investigation was comprised of eight varieties of potato which was shown in Randomized complete block design with three replications. The result indicated that, potato variety Kufri Arun was observed best for growth i.e. days to $50 \%$ germination (18.85\%), no. of branches plant ${ }^{-1}(4.0,5.73,8.53$ at $30,45,60$ DAP), plant height $(23.22,44.30,59.35 \mathrm{~cm})$, no. of leaves plant ${ }^{-1}(11.07,17.40,19.83)$, leaf length $(5.20$, $5.66,5.82 \mathrm{~cm})$, leaf width $(3.83,4.46,4.49 \mathrm{~cm})$, diameter of stem $(3.01,3.25,3.85$ $\mathrm{cm})$ and dry weight plant ${ }^{-1}(22.26,23.17,60.34 \mathrm{~g})$, leaf area plant ${ }^{-1}(208.30,396.36$, $\left.4.84 .13 \mathrm{~cm}^{2}\right)$, leaf area index $(0.173,0.330,0.404)$, net assimilation rate $(0.049,0.0746$ $\mathrm{mg} \mathrm{cm}{ }^{2}$ day $^{-1}$ at $45-30$ and $60-45$ DAP ) and crop growth rate $\left(0.1347,1.2390 \mathrm{~g} \mathrm{~cm}^{2}\right.$ day $^{-1}$ ) respectively, yield characters i.e. early days to haulm cutting (75), days to early maturity (90), number of rottubers plant ${ }^{-1}(1.00)$, weight of rottubers plant ${ }^{-1}(40.66 \mathrm{~g})$, total tubers yield plot ${ }^{-1}(32.55 \mathrm{~kg})$, marketable total tubers yield plot $^{-1}(32.02 \mathrm{~kg})$, total tubers yield $\left(361.63 \mathrm{q} \mathrm{ha}^{-1}\right)$, total marketable tubers yield $\left(355.82 \mathrm{q} \mathrm{ha}^{-1}\right)$ was recorded maximum with KufriArun, it was also observed best in qualitative traits. Maximum marketable tuber yield of $355.82\left(\mathrm{q} \mathrm{ha}^{-1}\right)$ was obtained in KufriArun by net return of ₹ $277036\left(\mathrm{ha}^{-1}\right)$ and cost benefit ratio 1:4.52. Hence, adoptability of KufriArun for commercial production in malwa condition would be best.
\end{abstract}

\section{Introduction}

Potato (Solanum tuberosum L.) is an important food crop and ranks fourth in importance globally next to rice, wheat and maize (Muthoni et al., 2011). It is mainly utilized in the form of table stock $(31 \%)$, frozen french fries $(30 \%)$, chips and shoestrings (12\%) and dehydrated products (12\%) (Miranda and Aguilera, 2006). The crop has the ability to produce maximum quantity within minimum time and with use of minimum water (Lamboro et al., 2014). Thus, potato has the ability to save millions of hungry people in developing countries and malnourishment. Among the carbohydrates, sucrose, glucose and fructose are the major constituents in potato (Marecek et al., 2013).

Potato production and productivity in India had shown gradual and steady increase in the last 50 years and at present, India ranks fourth in area and third in production in the world (Saran and Chhabra, 2014), currently in India the area of potato are 1973.2 ('000 ha), production 41555.4 ('000 MT), $21.1\left(\mathrm{MT} \mathrm{ha}^{-1}\right)$ has been estimated during 2013-2014. Major growing states in India are Uttar Pradesh, Bihar, West Bengal, Punjab, Karnataka, Assam and Madhya Pradesh. In Madhya Pradesh the area of potato are 110.0 ('000 ha), production 2322.4 ('000 MT), 21.1 (MT ha-1). Shajapur, Jabalpur, Indore, Chhindwara and Satna are the major growing areas in the state.

Postharvest improvement such as fast and cheap transportation, storage and processing will help to make potato production more profitable for farmers by improving their access to markets, raising local value addition. But due to number of production problems that accounts for low regional as well as national yield have been identified. The major ones are lack of stable, well-adapted, disease and insect pests tolerant varieties (Tesfaye and Yigzaw, 2008). Although, there are so many varieties of potato i.e. Kufri Jawahar, Kufri Sinduri, Kufri Kisan, Kufri Chamatkar, Kufri Sheetman, Kufri Arun, 
Kufri Lauvkar, Kufri Surya etc. available in local market but their performance has not been tested under our condition so for there is a great confusion regarding the selection of right variety in our condition due to poor knowledge on this aspect. The growers of this region are suffering up to a great extent not only due to low production, poor keeping quality of tubers but also biotic stress such as late blight, common scab, and mosaic virus. In view of the above facts, the present studies in potato have been carried out.

\section{Materials and Methods}

\subsection{Description of the study area}

The present investigation entitled "Assessment of varietal performance in diverse Potato (Solanum tuberosum L.) genotypes" was carried out during the year 2013-2014 at the Research Farm of Department of Horticulture, College of Agriculture, Indore, Rajmata Vijayaraje Scindia Krishi Vishwa Vidyalaya, Gwalior (Madhya Pradesh). The soil of the experimental field has been grouped under medium black clay soil (Vertisols). Indore is situated in Malwa plateau region in the Western part of the state of Madhya Pradesh at an altitude of $555.5 \mathrm{~m}$ amsl. It is located at latitude $22.43^{\circ} \mathrm{N}$ and longitude of $75.66^{\circ} \mathrm{E}$. It has subtropical climate having a temperature range of $21{ }^{\circ} \mathrm{C}$ to $45^{\circ} \mathrm{C}$ and $6{ }^{\circ} \mathrm{C}$ to $31^{\circ} \mathrm{C}$ in summer and winter seasons, respectively.

\subsection{Method of data collection}

The experimental material for the present investigation was comprised of eight varieties of potato i.e (Kufri Chipsona-1, Kufri Chipsona-2, Kufri Chipsona-4, Kufri Jawahar, Kufri Chandramukhi, Kufri Arun, Kufri Lauvkar, Kufri Surya), these varieties were sown in Randomized Complete Block Design with three replications, to observed morphological, growth, yield and quality parameters. The size of plot was $3.0 \times 3.0 \mathrm{~m}^{2}$. and the crop was sown with a spacing of $60 \times 20$ $\mathrm{cm}^{2}$. Observations were recorded on the basis of five random competitive plants selected from each genotype separately for growth parameters viz., days to $50 \%$ germination, number of branches plant ${ }^{-1}$, plant height $(\mathrm{cm})$, number of leaves plant ${ }^{-1}$, length of leaves $(\mathrm{cm})$, width of leaves $(\mathrm{cm})$, diameter of stem $(\mathrm{cm})$ and dry weight plant ${ }^{-1}(\mathrm{~g})$. Yield parameters viz., days to haulm cutting, days to maturity, number of tubers plant ${ }^{-1}$, number of rotted tubers plant ${ }^{-1}$, weight of rot tubers plant ${ }^{-1}$, total tubers yield plot $^{-1}$, total tubers yield hectare ${ }^{-1}\left(\mathrm{q} \mathrm{ha}^{-1}\right)$, marketable yield plot $^{-1}$, marketable yield hectare ${ }^{-1}\left(\mathrm{q} \mathrm{ha} \mathrm{h}^{-1}\right)$. Quality parameter viz., dry matter of tuber, quality of chips. Physiological parameters viz., Leaf area plant ${ }^{-1}\left(\mathrm{~cm}^{2}\right)$. At random three plants form each genotype and replication were uprooted and cleaned. The assimilatory surface area (A) was recorded by using electronic leaf area meter (Li Cor 3000) at 90 days after transplanting.
Leaf area index (LAI)-The assimilatory surface area (A) was recorded in at random three plants from each genotype and replications by using electronic leaf area meter ( $\mathrm{Li} \mathrm{Cor} \mathrm{3000).}$ LAI is the leaf area (A) or the assimilatory surface area over a certain ground area $(\mathrm{P})$ and is calculated by the formula given by (Watson, 1952) at 90 DAT.

where,

$\mathrm{A}=$ Leaf area

$$
\mathrm{LAI}=\frac{\mathrm{A}}{\mathrm{P}}
$$

$\mathrm{P}=$ Ground area

Net assimilation rate (NAR)-It is themeasurement of the rate of photosynthesis unit ${ }^{-1}$ time on the basis of dry matter and is expressed as $\mathrm{g} \mathrm{cm}^{-2}$ day $^{-1}$. It was worked out as per the following formula (Watson, 1952).

Where,

$$
\mathrm{NAR}=\frac{\mathrm{W}_{2}-\mathrm{W}_{1}}{\mathrm{~A}_{2}-\mathrm{A}_{1}} \times \frac{\log \mathrm{A}_{2}-\log \mathrm{A}_{1}}{\left(\mathrm{t}_{2}-\mathrm{t}_{1}\right)}
$$

$A_{1}$ and $W_{1}$ are the leaf area and dry weight of the plant sample respectively at time $t_{1}$ and $\mathrm{A}_{2}$ and $\mathrm{W}_{2}$ are the leaf area and dry weight of the plant sample respectively at time $t_{2}$.

Crop growth rate (CGR)-Crop growth rate also called the rate of dry matter production (Blackman and Black, 1968). The crop growth rate is expressed as $\mathrm{g} \mathrm{m}^{-2} \mathrm{day}^{-1}$.

where, $\mathrm{C}=\left(\mathrm{W}_{2}-\mathrm{W}_{1}\right) /\left(\mathrm{T}_{2}-\mathrm{T}_{1}\right) \times 1 / \mathrm{GA}$

GA: Ground area

$\mathrm{W}_{1}=$ Dry weight of plant at $1^{\text {st }}$ observation.

$\mathrm{W}_{2}=$ Dry weight of plant at $2^{\text {nd }}$ observation.

$\mathrm{T}_{1} \& \mathrm{~T}_{2}=$ Interval between observation.

The data based on the mean of individual plants selected for observation were statistically analyseddescribed by Panse and Sukhatme (1985) to find out overall total variability present in the material under study for each character and for all the populations. The procedures used for working out economics of different treatments under consideration were as suggested by Yang et al. (1989).

\section{Results and Discussion}

\subsection{Growth parameters}

Among growth parameters the days to $50 \%$ germination, plant height, number of branches plant ${ }^{-1}$, number of leaves plant $^{-1}$, leaf length, leafwidth, diameter of stemand dry weight plant ${ }^{-1}$ were studies in potato (Table 1). Significantly minimum days required for $50 \%$ germination was recorded in variety Kufri Arun followed by Kufri Chandramukhi and Kufri Lauvkar as compared to other varieties. While, maximum days was recorded in Kufri Chipsona-4. Probable 


\begin{tabular}{|c|c|c|c|c|c|c|c|c|}
\hline \multirow[t]{3}{*}{ Genotypes } & \multirow[t]{3}{*}{$\begin{array}{c}\text { Days } \\
\text { to } 50 \% \\
\text { germination }\end{array}$} & $\begin{array}{c}\text { No. of } \\
\text { branches } \\
\text { plant }^{-1}\end{array}$ & $\begin{array}{l}\text { Plant } \\
\text { height } \\
(\mathrm{cm})\end{array}$ & $\begin{array}{l}\text { No. of } \\
\text { leaves } \\
\text { plant }^{-1}\end{array}$ & $\begin{array}{l}\text { Leaf } \\
\text { length } \\
(\mathrm{cm})\end{array}$ & $\begin{array}{l}\text { Leaf } \\
\text { width } \\
(\mathrm{cm})\end{array}$ & $\begin{array}{l}\text { Diameter } \\
\text { of stem } \\
(\mathrm{cm})\end{array}$ & $\begin{array}{c}\text { Dry } \\
\text { weight of } \\
\text { plant }(g)\end{array}$ \\
\hline & & At 60 & At 60 & At 60 & At 60 & At 60 & At 60 & At 60 \\
\hline & & DAP & DAP & DAP & DAP & DAP & DAP & DAP \\
\hline Kufri Chipsona-1 & 22.00 & 8.13 & 58.05 & 16.73 & 5.34 & 4.22 & 3.41 & 40.20 \\
\hline Kufri Chipsona-2 & 22.45 & 7.30 & 53.25 & 16.14 & 5.02 & 3.96 & 3.12 & 28.44 \\
\hline Kufri Chipsona-4 & 23.16 & 7.10 & 48.30 & 15.80 & 4.80 & 3.86 & 3.01 & 22.19 \\
\hline Kufri Jawahar & 22.20 & 8.00 & 57.60 & 16.52 & 5.28 & 4.12 & 3.34 & 38.28 \\
\hline K. Chandramukhi & 20.25 & 8.40 & 58.87 & 18.37 & 5.75 & 4.41 & 3.65 & 56.34 \\
\hline Kufri Arun & 18.85 & 8.53 & 59.35 & 19.83 & 5.82 & 4.49 & 3.85 & 60.34 \\
\hline Kufri Lauvkar & 21.18 & 8.27 & 58.65 & 17.20 & 5.60 & 4.34 & 3.53 & 43.83 \\
\hline Kufri Surya & 22.32 & 7.83 & 55.20 & 16.28 & 5.15 & 4.02 & 3.22 & 38.74 \\
\hline $\operatorname{SEm} \pm$ & 0.44 & 0.08 & 0.23 & 0.16 & 0.07 & 0.02 & 0.15 & 0.55 \\
\hline $\mathrm{CD}(p=0.05)$ & 1.35 & 0.27 & 0.70 & 0.50 & 0.21 & 0.08 & 0.47 & 1.68 \\
\hline
\end{tabular}

reasons for time of germination varies from variety to variety and physiologically older tubers emerge early as compared to the younger ones. These findings are in agreement with the findings of Kumar et al. (2011). As regards to 60 day after transplanting, varieties Kufri Arun, Kufri Chandramukhi and Kufri Lauvkar were recorded in significantly maximum branches plant $^{-1}$ and which were at par with each other. However, it was observed lowest in variety Kufri Chipsona-4. Probable reason for increased number of branches due to the increased rates of photosynthesis and photosynthates supply for maximum branches growth or change in endogenous auxin in turn in apical dominance. These findings are in agreement with the findings of Nandekar et al. (1995). In case of 60 days after planting, the significantly maximum leaves plant ${ }^{-1}$ was recorded in variety Kufri Arun followed by Kufri Chandramukhi, Kufri Lauvkar and Kufri Chipsona-1 as compared to other varieties. Therefore, it was observed minimum in variety Kufri Chipsona-4. These finding are in agreement with the findings reported by Kumar et al. (2007a); Singh et al. (2010). At 60 day after transplanting, varieties Kufri Arun, Kufri Chandramukhiand Kufri Lauvkar were recorded in significantly maximum plant height and which were at par with each other. However, it was observed lowest in variety Kufri Chipsona-4. Similar results have been reported by Singh et al. (2010); Kumar (2011), Singh et al. (2011); Zheng Xu et al. (2012); Patel et al. (2013); Ahmad et al. (2013). The significantly maximum leaf length was recorded under the variety Kufri Arun followed by Kufri Chandramukhi, Kufri Lauvkar and Kufri Chipsona-1 as compared to other varieties. Therefore, it was observed minimum in variety Kufri Chipsona-4 at 60 days after planting. These findings are in agreement with the findings of Hossain et al. (1995). At 60 days after planting, the significantly maximum leaf width was recorded under the varieties Kufri Arun and Kufri Chandramukhi and which were at par with each other. While, minimum leaf width was recorded invariety Kufri Chipsona-4. The significantly maximum diameter of stem was recorded in varieties Kufri Arun, Kufri Chandramukhi, Kufri Lauvkar and Kufri Chipsona-1 and which were at par with each other. Therefore, it was observed minimum in variety Kufri Chipsona- 4 . These finding are in agreement with the findings reported by Zheng Xu et al. (2012). In case of 60 day after transplanting, the dry weight plant ${ }^{-1}$ was significantly increased by the different varieties. The Kufri Arun was found significantly superior as compared to other varieties. Highest dry weight plant ${ }^{-1}$ was recorded in variety Kufri Arun, followed by Kufri Chandramukhi which recorded and Kufri Lauvkar. However, lowest dry weight plant ${ }^{-1}$ was noted in the variety

\subsection{Physiological parameters}

Among growth analyticalparameters, leaf area plant ${ }^{-1}$, leaf area index, net assimilation rate and crop growth rate were studies in potato (Table 2). The leaf area plant ${ }^{-1}\left(\mathrm{~cm}^{2}\right)$ of potato increased significantly with the different genotypes. At 60 day after transplanting, Kufri Arun was recorded significantly maximum leaf area plant ${ }^{-1}$ followed by Kufri Chandramukhi, Kufri Lauvkar and Kufri Chipsona-1 as compared to other varieties. Therefore, it was observed minimum in variety Kufri Chipsona-4. Similar results have been reported by Ummyiah et al. (2010); Zheng Xu et al. (2012). At 60 day after transplanting, variety Kufri Arun was recorded significantly maximum leaf area indexfollowed by 
Table 2: Response of different varieties of potato on physiological parameter

\begin{tabular}{lcccc}
\hline Genotypes & $\begin{array}{c}\text { LAP } \\
\left(\mathrm{cm}^{2}\right)\end{array}$ & LAI & $\begin{array}{c}\text { NAR } \\
\left(\mathrm{g} \mathrm{cm}^{-2}\right. \\
\left.\text { day }^{-1}\right)\end{array}$ & $\begin{array}{c}\text { CGR } \\
\left(\mathrm{g} \mathrm{m}^{-2}\right. \\
\left.\text { day }^{-1}\right)\end{array}$ \\
\cline { 2 - 5 } & $\begin{array}{c}\text { At } 60 \\
\text { DAP }\end{array}$ & $\begin{array}{c}\text { At } 60 \\
\text { DAP }\end{array}$ & $\begin{array}{c}\text { At } 60 \\
\text { DAP }\end{array}$ & $\begin{array}{c}\text { At } 60 \\
\text { DAP }\end{array}$ \\
\hline Kufri Chipsona-1 & 417.85 & 0.348 & 0.0360 & 0.6277 \\
Kufri Chipsona-2 & 323.78 & 0.270 & 0.0152 & 0.2997 \\
Kufri Chipsona-4 & 295.72 & 0.246 & 0.0053 & 0.1043 \\
Kufri Jawahar & 377.07 & 0.314 & 0.0326 & 0.6263 \\
K. Chandramukhi & 438.89 & 0.365 & 0.0556 & 1.1278 \\
Kufri Arun & 484.13 & 0.404 & 0.0746 & 1.2390 \\
Kufri Lauvkar & 421.01 & 0.351 & 0.0401 & 0.7363 \\
Kufri Surya & 340.79 & 0.284 & 0.0320 & 0.5850 \\
SEm \pm & 5.07 & 0.004 & 0.0028 & 0.0180 \\
CD $(p=0.05)$ & 15.40 & 0.013 & 0.0086 & 0.054 \\
\hline
\end{tabular}

LAP: Leaf area plant $^{-1}$; LAI: Leaf area index; NAR: Net assimilation rate; CGR: Crop growth rate

Kufri Chandramukhi, Kufri Lauvkar and Kufri Chipsona-1 as compared to other varieties. While, it was observed minimum leaf area indexin variety Kufri Chipsona-4. These finding are in agreement with the findings reported by Channappagoudar et al. (2007); Singh et al. (2011); Muthoni et al. (2011). The data clearly showed that there was significant difference amongst the varieties at all stages of observations. The NAR in general increased at $60 \mathrm{DAP}$ in all the varieties. At 60 day after transplanting, the highest $\left(0.0746 \mathrm{~g} \mathrm{~cm}^{-2}\right.$ day $\left.^{-1}\right)$ net assimilation rate was found in Kufri Arun followed by
Kufri Chandramukhi $\left(0.0556 \mathrm{~g} \mathrm{~cm}^{-2}\right.$ day $\left.^{-1}\right)$ and Kufri Lauvkar $\left(0.0401 \mathrm{~g} \mathrm{~m}^{-2}\right.$ day $\left.^{-1}\right)$. The lowest $\left(0.0053 \mathrm{~g} \mathrm{~cm}^{2}\right.$ day $\left.^{-1}\right)$ was observed in Kufri Chipsona-4. This revealed that, the leaf area index increased the shading effect of the leaves may have caused reduction in photosynthesis and NAR. It may also be due to the reduced photosynthesis of the older leaves. These findings are in agreement with the results reported by Channappagoudar et al. (2007). It is obvious from the deta clearly indicated that there was significant difference amongst the varieties at all the stages of observations. In generalcrop growth rate (CGR) increased with increase in crop growth stages. At $60 \mathrm{DAP}$, the significantly highest $1.2390 \mathrm{~g} \mathrm{~cm}^{2}$ day ${ }^{1}$ crop growth rate were observed in the variety Kufri Arun followed by Kufri Chandramukhi $\left(1.1278 \mathrm{~g} \mathrm{~cm}^{-2}\right.$ day $\left.^{-1}\right)$ and Kufri Lauvkar $\left(0.7363 \mathrm{~g} \mathrm{~cm}^{-2}\right.$ day $\left.^{-1}\right)$. However, the lowest $\left(0.1043 \mathrm{~g} \mathrm{~cm}^{-2}\right.$ day $\left.^{-1}\right)$ crop growth rate was found in Kufri Chipsona-4 as compared to other varieties. These finding are in agreement with the findings reported by Channappagoudar et al. (2007); Ahmad et al. (2013).

\subsection{Yield parameters}

Among yield parameters, viz., days to haulm cutting, days for maturity, number of rotted tubers plant ${ }^{-1}$, weight of rotted tubers plant ${ }^{-1}$, total yield of tubers plot ${ }^{-1}$, total yield of tubers ha $^{-1}$, marketable tuber yield plot ${ }^{-1}$ and hectare ${ }^{-1}$ was studies in potato (Table 3 ). The significantly early 60 days for haulm cutting was recorded in the variety Kufri Chandramukhi followed by Kufri Lauvkar ( 65 days) and Kufri Arun ( 75 days) as compared to other varieties. However, the variety Kufri Chipsona-2 was exhibited maximum 105 days for haulm cutting. These finding are in agreement with the findings reported by Suhag et al. (2006). The minimum days for

\begin{tabular}{lccccccccccc}
\hline \multicolumn{1}{l}{ Table 3: Response of different potato varieties on yield and quality parameter } \\
\hline Genotypes & DHC & DM & NRTP & $\begin{array}{c}\text { WRTP } \\
(\mathrm{g})\end{array}$ & $\begin{array}{c}\text { TYTP } \\
(\mathrm{kg})\end{array}$ & $\begin{array}{c}\text { TYT } \\
\text { ha }^{-1}(\mathrm{q})\end{array}$ & $\begin{array}{c}\text { MYTP } \\
(\mathrm{kg})\end{array}$ & $\begin{array}{c}\text { MYT } \\
(\mathrm{q})\end{array}$ & $\begin{array}{c}\text { Dry } \\
\text { matter \% }\end{array}$ & $\begin{array}{c}\text { Potato } \\
\text { flour }\end{array}$ & \begin{tabular}{c} 
QC \\
\hline Kufri Chipsona-1
\end{tabular} \\
& 85.00 & 100.00 & 1.53 & 59.95 & 25.200 & 279.97 & 24.817 & 275.72 & 24.25 & LGC & Good \\
Kufri Chipsona-2 & 105.00 & 120.00 & 2.33 & 88.82 & 20.317 & 225.72 & 19.917 & 221.27 & 24.02 & LGC & Good \\
Kufri Chipsona-4 & 95.00 & 110.00 & 2.67 & 106.02 & 10.333 & 114.81 & 10.003 & 111.14 & 22.34 & LGC & Good \\
Kufri Jawahar & 85.00 & 100.00 & 1.67 & 59.98 & 24.393 & 271.01 & 23.583 & 262.01 & 20.94 & GC & Fair \\
Kufri Chandramukhi & 60.00 & 75.00 & 1.25 & 49.12 & 29.867 & 331.82 & 29.197 & 324.37 & 23.17 & GC & Good \\
Kufri Arun & 75.00 & 90.00 & 1.00 & 40.66 & 32.550 & 361.63 & 32.027 & 355.82 & 25.13 & GC & Good \\
Kufri Lauvkar & 65.00 & 80.00 & 1.33 & 54.45 & 25.500 & 283.31 & 24.847 & 276.05 & 18.86 & GC & Good \\
Kufri Surya & 85.00 & 100.00 & 2.00 & 79.86 & 23.633 & 262.57 & 23.117 & 256.83 & 25.10 & GC & Fair \\
SEm \pm & 0.75 & 0.75 & 0.27 & 12.80 & 1.43 & 15.98 & 1.45 & 16.20 & 0.01 & - & - \\
CD $(p=0.05)$ & 2.29 & 2.29 & 0.83 & 38.83 & 4.36 & 48.50 & 4.42 & 49.16 & 0.06 & - & - \\
\hline
\end{tabular}

DHC: Days to haulm cutting; DM: Days to maturity; NRTP: No. of rotted tubers plant ${ }^{-1}$; WRTP: Weight of rotted tubers plant $^{-1}$; TYTP: Total yield of tubers plot ${ }^{-1}$; TYT: Total yield of tubers; MYTP: Marketable yield of tubers plot $^{-1}$; MYT: Marketable yield of tubers ha-1 ${ }^{-1}$ QC: Quality of chips; LGC: Light golden colour; GC: Golden colour 
maturity (75.0 days) were observed for Kufri Chandramukhi followed by Kufri Lauvkar ( 80 days) and Kufri Arun ( 90 days) as compared to other varieties. However, the varieties Kufri Chipsona-2 and Kufri Chipsona-4 were required maximum 120 and 110 days for maturity, respectively. These finding are in agreement with the findings reported by Bhutani et al. (2003); Suhag et al. (2006). Significantly minimum number of rot tubers plant ${ }^{-1}$ was recorded in Kufri Arun, Kufri Chandramukhi, Kufri Lauvkar, Kufri Chipsona-1 and Kufri Jawahar. Therefore, it was observed maximum in variety Kufri Chipsona-4. These finding are in agreement with the findings reported by Shibairo et al. (2006). Kufri Arun, Kufri Chandramukhi, Kufri Lauvkar, Kufri Chipsona-1 and Kufri Jawahar were noted significantly minimum weight of rot tubers plant $^{-1}$. While it was found maximum in Kufri Chipsona-4, these finding are in agreement with the findings reported by Kumar, (2009). Kufri Arun was recorded significantly superior and gave maximum $\left(32.550 \mathrm{~kg} \mathrm{plot}^{-1}\right)$ total yield of tubers plot $^{-1}$ and followed by Kufri Chandramukhi (29.867 $\left.\mathrm{kg} \mathrm{plot}^{-1}\right)$ and which were at par with each other. While, the lowest $(10.333 \mathrm{~kg})$ total yield of tubers plot $^{-1}$ was noted in variety Kufri Chipsona-4. Finding corroborates with their results obtained by Ummyiah et al. (2010). Variety Kufri Arun was recorded significantly superior and gave maximum (361.63 q) total yield of tubers $\left(\mathrm{ha}^{-1}\right)$ and which were at par with Kufri Chandramukhi (331.82 q ha- ${ }^{-1}$ ). While, the lowest (114.81 q ha $\mathrm{q}^{-1}$ ) total yield was noted in Kufri Chipsona-4. Finding corroborates with their results obtained by Ummyiah et al. (2010); Sen et al. (2010); Singh et al. (2010); Kumar (2011); Singh et al. (2011); Lakshmi et al. (2011); Ghulam Abbas Hafiz et al. (2012); Patel et al. (2013); Ahmad et al. (2013). Significantly maximum (32.027), (29.197 kg plot ${ }^{-1}$ ) and $\left(355.82 \mathrm{q} \mathrm{ha}^{-1}\right),\left(324.37 \mathrm{q} \mathrm{ha}^{-1}\right)$ marketable tuber yield were recorded under the varieties Kufri Arun and Kufri Chandramukhi, respectively and which were at par with each other. However, the lowest (10.003 $\left.\mathrm{kg} \mathrm{plot}^{-1}\right)$ and (111.14 q ha $\left.{ }^{1}\right)$ marketable tuber yield was observed in Kufri Chipsona-4. The higher yield might be due to increase in plant height, number of leaves, and yield attributes i.e, size of tubers, fresh weight of whole plant, fresh and dry weight of tubers. This might be due to the availability of the nutrients in readily available form and the $\mathrm{C}: \mathrm{N}$ was high. These finding are in agreement with the findings reported by Sen et al. (2010); Singh et al. (2010); Singh et al. (2011); Patel et al. (2013); Prasad et al. (2013).

\subsection{Quality parameters}

Among quality parameters, the dry matter per cent, potato flour and chips were studies in potato (Table 3). Significantly maximum dry matter was observed in the variety Kufri Arun followed by Kufri Chipsona-1, Kufri Chipsona-2 and Kufri
Chandramukhi as compared to other varieties. Whereas, the lowest dry matter was noted in Kufri Lauvkar. Potato varieties differ in their dry matter. Variation in dry matter was due to the inherent genetic makeup of the variety. These finding are in agreement with the findings reported Gautam et al. (2012); Ghulam Abbas Hafiz et al. (2012); Zheng Xu et al. (2012); Patel et al. (2013); Ahmad et al. (2013). Kufri Chipsona-1, Kufri Chipsona-2, Kufri Chipsona-4 and Kufri Surya exhibited light golden colour flour and remaining varieties was observed golden colour flour. This may be due to inherent genetic makeup of the variety. These finding are in agreement with the findings reported by Singh et al. (2005a). Quality of chips was determined on its taste and colour. Generally good taste and light coloured chips are preferable. Results revealed that the chips produced from Kufri Chipsona-1,-2,-4, Kufri Chandramukhi, Kufri Arun and Kufri Lauvkar were superior than Kufri Jawahar and Kufri Surya. This may be due to processing should be meet the minimum requirement such as shape, size texture, dry matter, reducing sugar and starch. These finding are in agreement with the findings reported by Muller et al. (2009); Gautam et al. (2012); Patel et al. (2013) and Das et al. (2014).

\subsection{Economics of potato production}

It is revealed from the data (Table 4) obtained that a significantly maximum marketable tuber yield of (355.82 $\mathrm{q} \mathrm{ha}^{-1}$ ) was obtained in potato variety Kufri Arun with net return of ₹ $\left(277036 \mathrm{ha}^{-1}\right)$ with sealing product at average

\begin{tabular}{|c|c|c|c|c|c|}
\hline Genotypes & $\begin{array}{c}\text { Fruit } \\
\text { yield } \\
\left(\mathrm{q} \mathrm{ha}^{-1}\right)\end{array}$ & $\begin{array}{l}\text { Gross } \\
\text { income } \\
\left(₹ \mathrm{ha}^{-1}\right)\end{array}$ & $\begin{array}{c}\mathrm{CC} \\
\left(₹ \mathrm{ha}^{-1}\right)\end{array}$ & $\begin{array}{c}\text { Net } \\
\text { income } \\
\left(₹ \mathrm{ha}^{-1}\right)\end{array}$ & $\begin{array}{l}\mathrm{C}: \mathrm{B} \\
\text { ratio }\end{array}$ \\
\hline $\begin{array}{l}\text { Kufri } \\
\text { Chipsona-1 }\end{array}$ & 275.72 & 275720 & 78784 & 196936 & $1: 3.50$ \\
\hline $\begin{array}{l}\text { Kufri } \\
\text { Chipsona-2 }\end{array}$ & 221.27 & 221270 & 78784 & 142486 & $1: 2.81$ \\
\hline $\begin{array}{l}\text { Kufri } \\
\text { Chipsona-4 }\end{array}$ & 111.14 & 111140 & 78784 & 32356 & $1: 1.41$ \\
\hline $\begin{array}{l}\text { Kufri } \\
\text { Jawahar }\end{array}$ & 262.01 & 262010 & 78784 & 183226 & $1: 3.33$ \\
\hline $\begin{array}{l}\text { K. Chandr- } \\
\text { amukhi }\end{array}$ & 324.37 & 324370 & 78784 & 245586 & $1: 4.12$ \\
\hline $\begin{array}{l}\text { Kufri } \\
\text { Arun }\end{array}$ & 355.82 & 355820 & 78784 & 277036 & $1: 4.52$ \\
\hline $\begin{array}{l}\text { Kufri } \\
\text { Lauvkar }\end{array}$ & 276.05 & 276050 & 78784 & 197266 & $1: 3.50$ \\
\hline Kufri Surya & 256.83 & 256830 & 78784 & 178046 & $1: 3.26$ \\
\hline
\end{tabular}

CC: Cost of cultivation 
market price of potato ₹ $\left(1000 \mathrm{q}^{-1}\right)$, cost benefit ratio 1:4.52 followed by Kufri Chandramukhi were recorded ( $324.37 \mathrm{q}$ ha1) tuber yield along with net return of ₹ $\left(245586 \mathrm{ha}^{-1}\right)$ and cost benefit ratio 1: 4.12. Whereas, the lowest tuber yield 111.14 q ha ${ }^{-1}$ ) was recorded in Kufri Chipsona-4 with net return of ₹ $\left(32356 \mathrm{ha}^{-1}\right)$ and cost benefit ratio 1:1.41. These finding are in agreement with the findings reported by Dash (2008), Singh et al. (2010); Shivay (2010); Singh et al. (2011); Rajesh Kumar et al. (2013).

\section{Conclusion}

Potato variety Kufri Arun responded well in terms of growth, growth analytical, yield and quality parameters and suitable for commercial production in Malwa condition. Chips produced from Kufri Chipsona-1,-2,-4, Kufri Chandramukhi, Kufri Arun and Kufri Lauvkar were superior than Kufri Jawahar and Kufri Surya, this may be due to processing should be meet the minimum requirement such as shape, size texture, dry matter, reducing sugar and starch.

\section{References}

Ahmad, A., Pal, M., Khetarpal, S., Pandey, S.K., 2013. Impact of elevated atmospheric $\mathrm{CO}_{2}$ concentration on growth and yield of potato cultivars. World Applied Sciences Journal 24(4), 429-435.

Bhutani, R.D., Sanwal, S.K., Khurana, S.C., 2003. Variation in the quality of potato (Solanum tuberosum L.) tubers with crop maturity. Haryana Journal of Horticultural Sciences 32(1/2), 110-113.

Blackman, G.E., Black, J.N., 1968. Physiological and ecological studies in analysis of plant environment. Annalsof Botany 23(89), 51-63.

Channappagoudar, B.B., Biradar, N.R., Bharmagoudar, T.D., Koti, R.V., 2007. Influence of herbicides on morphophysiological growth parameters in potato. Karnataka Journal of Agricultural Sciences 20(3), 487-491.

Das, B., Sarkar, K.K., Priya, B., Dudhane, A.S., Pradhan, A.M., Das, A., 2014. Evaluation of early and late harvested potatoes for yield, quality and storability. International Journal of Bio-resource and Stress Management 5(1), 22-30.

Dash, S.N., 2008. Effect of different levels of fertilizers and seedling tuber sizes on growth, yield and economics of potato production. Orissa Journal of Horticulture 36(2), 20-23.

Gautam, I.P., Khatri, B.B., Sharma, M.D., Thapa, R.B., Shrestha, K., Chaudhary, D., 2012. Evaluation of potato genotypes for keeping quality under ambient conditions in Nepal. Potato Journal 39(2), 128-132.

Ghulam Abbas Hafiz, I.A., Abbasi, N.A., Hussain, A., 2012.
Determination of processing and nutritional quality atributes of potato genotypes in Pakistan. Pakistan Journal of Botany 44(1), 201-208.

Kumar, P., Pandey, S.K., Singh, B.P., Singh, S.V., Kumar, D., 2007a. Influence of source and time of potassium application on potato growth, yield, economics and crisp quality. Potato Research 50(1), 1-13.

Kumar, S., 2009. Performance study of indigenous potato hybrids K-22 and G-4 in eastern plains. Haryana Journal of Horticultural Sciences 38(1/2), 154-155.

Kumar, S., 2011. Stability analysis in potato (Solanum tuberosum L.) for yield and quality traits. Annals of Biology 27(2), 147-151.

Lakshmi, D.V., Padmaja, G., Rao, P.C., 2011. Effect of levels of nitrogen and potassium on yield, uptake and economics of potato grown on alfisols of Andhra Pradesh. Journal of Research ANGRAU 39(4), 59-62.

Lamboro, A., Petros, Y., Andargie, M., 2014. Correlation and path coefficient analysis between yield and yield components in potato (Solanum tuberosum L.). Plant Science Today 1(4), 196-200.

Marecek, J., Francakova, B.T., Fikselova, M., Mendelova, A., Ivanisova, E., 2013. Carbohydrates in varieties of stored potatoes and influence of storage on quality of fried products. Journal of Microbiol, Biotechnol and Food Science 2(1), 1744-53.

Miranda, M., Aguilera, J.M., 2006. Structure and texture properties of fried potato products. Food Review International 22, 173-01.

Muller, D.R., Bisognin, D.A., Andriolo, J.L., Morin Junior, G.R., Gnocato, F.S., 2009. Trait expression and selection of potato clones in the spring and autumn growth conditions. Ciencia Rural 39(5), 1327-1334.

Muthoni, J., Miriam, M., Jackson, N.K., 2011. Up-scaling production of certified potato seed tubers in Kenya: potential of aeroponics technology. Journal of Horticulture and Forestry 3(8), 238-43

Nandekar, D.N., Sharma, R.C., Sharma, T.R., 1995. Yield potential of potato hybrids in Madhya Pradesh. Journal of the Indian Potato Association 22(1-2), 13-16.

Panse, V.C., Sukhatme, P.V., 1985. Statistical methods for agricultural workers. ICAR Publications, New Delhi, 155.

Patel, A.K., Patel, N.H., Gami, R.A., Patel, C.R., Chauhan, R.M., 2013. Assessment of potato (Solanum tuberosum L.) hybrids-varieties for table purpose among yield and quality traits. Trends in Biosciences 6(5), 669-673.

Patel, J.C., Patel, L.R., Amin, A.U., Patel, J.K., 2007. Effect of irrigation and nitrogen levels on growth and yield of potato. Journal of the Indian Potato Association 27(1/2), $51-53$. 
Prasad, B.V., Vara Prasad, G.S., 2013. Genetic Variability, Trait Association and Path Analysis of Yield and Yield Components in (Vigna radiata L.) International journal of Bio-resource and Stress Management 4(2), 251-254.

Rajesh kumar, N.K., Raghavendra, K., Veeresh, J.M., Chowdareddy, M., Chowdegowda, M.G., 2013. Evaluation of drip irrigation over conventional furrow irrigation on yield and economics of potato (Solanum tuberosum L.) crop. International Agricultural Engineering Journal 22(3), 15-25.

Sarana, V.P., Chhabraa, P., 2014. Studies on the parameters of potato processing. Int. Interdisciplinary Research Journal 4, 320-33.

Sen, D., Amitava, R., Sarkar, N.C., Ghosh, D.C., Roy, S.K.B., 2010. Effect of transplanting dates and spacing on yield attributing character, productivity and economics of potato cultivation through true potato seed (TPS) technology. Italian Journal of Agronomy 5(1), 35-42.

Shibairo, S.I., Demo, P., Kabira, J.N., Gildemacher, P., Gachango, E., Menza, M., Nyankanga, R.O., Cheminingwa, G.N., Narla, R.D., 2006. Effects of gibberellic acid $\left(\mathrm{GA}_{3}\right)$ on sprouting and quality of potato seed tubers in diffused light and pit storage conditions. Journal of Biological Sciences 6(4), 723-733.

Shivay, Y.S., 2010. Effect of diammonium phosphate and mussoorie rock phosphate on productivity and economics of potato (Solanum tuberosum L.). Indian Journal of Agricultural Sciences 80(4), 329-332.

Singh, N., Sood, M.C., Singh, S.P., 2010. Yield and economics of potato (Solanum tuberosum L.) influenced by raised bed planting patterns and drip layout systems. Progressive Agriculture 10(1), 29-34.

Singh, Narpinder, Kaur, S.P., Kaur, Lovedeep, Sodhi, N.S., 2005a. Physicochemical, rheological and chapatti making properties of flour from some Indian potato cultivars. Journal of Food Science and Technology 42(4), 344-348.

Singh, S.K., Srivastava, A.K., Ramani, S., Lal, S.S., 2011. Effect of seed rate and integrated nutrient management on potato yield and economics under rainfed conditions in NEH region. Environment and Ecology 29(2), 550555.

Suhag, M., Nehra, B.K., Singh, N., Khurana, S.C., 2006. Storage behavior of potato under ambient condition affected by curing and crop duration. Haryana Journal of Horticultural Sciences 35(3\&4), 357-360.

Tesfaye, A., Yigzaw, D., 2008. Review of crop improvement research achievements and future focus in parts of western amhara region: the case of adet. In: TesfayeAbebe (ed.) proceedings of the $1^{\text {st }}$ Amhara region regional workshop on Potato research and development achievements and transfer experiences and future directions. Bahir Dar, Ethiopia, 85-101.

Ummyiah, H.M., Khan, S.H., Wani, K.P., Hussain, K., Junaif, N., 2010. Genetic variability in potato (Solanum tuberosum L.). Asian Journal of Horticulture 5(1), 6163.

Watson, D.J., 1952. The physiological basis of variation in yield. Advances in Agronomy 4, 101-146.

Yang, W.M., Chung, S.J., Yang, S.Y., 1989. Abstracts of Communications Papers. Korean Society of Horticultural Science 7, 54-55.

Xu, Z., Yi, D.Y., Kazuoto, I., Yutaka, J., 2012. Genotype differences of spatial distribution between potato (Solanum tuberosum L.) root and leaf and their effects on potato yield. China Vegetables (6), 48-52. 